\title{
Individuell «automagisk» tilbakemelding på skriftlig eksamen
}

\author{
Omid Mirmotahari og Yngvar Berg, \\ Instituttt for Informatikk, Universitetet $i$ Oslo
}

\begin{abstract}
I denne artikkelen viser vi et nytt system for å kunne gi delvis automatisk og formativ tilbakemelding til studenter på skriftlig eksamen. Vi vil belyse en ny måte å gi individuell tilbakemelding rettet mot hver enkelt students læring og fremtidige eksamensforberedelser. Den faglige tilbakemeldingen er utviklet for å gi studentene storre mulighet til å reflektere over egen besvarelse. Systemet er bygd opp slik at det bare medfører marginalt økt tidsbruk for sensurering ved å bruke systemet. Avslutningsvis har vi tatt med studentenes tilbakemeldinger på verdiskapningen dette systemet gir.
\end{abstract}

Keywords: Digital vurdering, automatisk tilbakemelding, formativ tilbakemelding.

\section{INTRODUKSJON OG MOTIVASJON}

De fleste studentene på høyere utdanning tar emner med en avsluttende skriftlig eksamen. Studenter som enten er misfornøyd med karakteren eller lurer på hva de gjorde dårlig på eksamen ber om en begrunnelse av karakteren. Denne begrunnelsen bruker studentene som grunnlag for eventuelt å klage på sensuren. Det viser seg at mange av de som ber om begrunnelse ikke har forstått hva de har gjort feil på eksamen. Studentene ønsker tilbakemelding for å forbedre forberedelse og prestasjon for framtidige eksamener. Vår erfaring fra undervisning på første semester, fjerde semester og masternivå er at vi ofte ser studentene gjøre de samme grunnleggende feilene gang på gang. Enkle tilbakemeldinger tidlig i studieløpet vil gi studentene bedre forutsetning for å tilegne seg læringsutbytte og for å forbedre prestasjon på eksamener. Nettopp derfor er det spesielt viktig å adressere dette for de aller ferskeste studentene slik at de kan utvikle gode vaner og eksamensteknikk. Vi ønsker å gi alle våre førsteårsstudenter individuell tilbakemelding på hvordan de besvarte eksamensoppgaver og hva de burde jobbe videre med. Spesielt ønsker vi å se framover på studentenes vegne og ønsker å ta $\mathrm{i}$ bruk feedforward prinsippet ved tilbakemelding, fremfor feedback [1-4]. Siden vårt arbeid hovedsakelig fokuser på førsteårsstudenter, er dette arbeidet også viktig i prosessen elev-tilstudent. Det er en helt annen situasjon å være student på et universitet enn elev på en videregående skole [5-6]. I høyere utdanning er det langt mer selvstendig arbeid og mindre tilbakemeldinger. Studier har vist at det å få tilbakemeldinger har stor påvirkning på læringsutbyttet. Det har vært gjennomført mange forsøk på å gi tilbakemeldinger, også noen få innen automatisering av tilbakemeldingene [7-10]. Denne artikkelen tar utgangspunkt i et introduksjonsemne (INF1400) i digital teknologi for førsteårsstudenter på institutt for Informatikk ved Universitetet i Oslo. Emnet har vi undervist i en rekke år og hvert år har vi gjort endringer og forbedringer både i form av pensum og læringsformer. Spesielt de siste årene har vi sett mer på vurderingsformene i emnet. Vi har gjort vurderinger i forhold til hvilke oppgaver som egner seg best for å gjøre en god summativ vurdering av læringen. Våre sensorveiledninger har blitt utvidet med årene og spesielt er det i de siste årene at vi har utviklet et eget dataprogram. Dette dataprogrammet er en form for sensorveiledning som gir sensorene større fleksibilitet. Programmet tilrettelegger sensureringen på en enkel måte ved at sensorene kun trenger å krysse av for utsagn.

\section{FAGLIG TILBAKEMELDING}

En sluttkarakter (A-F) gir studentene lite detaljinformasjon om hvordan de har gjort det på emnet. Hvilke deler av pensum har de god kunnskap i, presterte de godt nok i og hva kunne de 
ha gjort bedre? Dette er relevante spørsmål som vi har valgt å besvare med tilbakemelding til studentene. Vi ønsker å gi studentene tilbakemelding på hvordan de har løst eksamensoppgave faglig sett, det vil si en faglig tilbakemelding og ikke bare en faglig begrunnelse. Hvilke oppgaver har de klart og hvilke oppgaver må de jobbe mer med. I sensureringen har vi benyttet oss av en poengskala $0-10$, hvor 0 er blankt svar og 10 er full pott / komplett besvarelse. Sluttsummen for en besvarelse er et vektet resultat av hver deloppgave. Det er sluttsummen som blir omgjort til en karakter (A-F) basert på karaktergrensene satt av sensor og faglærer. Vi har gitt studentene (i tillegg til sluttkarakteren) en oversikt over deres poeng pr. oppgave. På den måten kan de selv se hvordan de har gjort det på hver deloppgave. For å kunne evaluere seg selv er det også viktig å vite hvordan de andre i samme kull har besvart samme oppgave og hvordan poengfordelingen har vært. For å kunne gi studentene muligheten til å reflektere over sin egen besvarelse og poeng/karakter har vi også utdelt et fellesnotat for årets eksamensresultater og en sensorveiledning, som viser fordelingen på del-oppgavene. Dette er vist i Tabell 1. Ved hjelp av denne tabellen kan studentene selv se hvordan de ligger ann i forhold til resten av kullet. Dette vil gi dem en indikasjon på hvilke oppgaver som ansees som «lette» (f.eks. 1c, 1d, 2a) og hvilke som er «vanskelige» (f.eks. 1e, 2e, 3, 4c, 5). Med utgangspunkt i tabellen ble det også utarbeidet gjennomsnittspoeng (Tabell 2) slik at studentene kunne sammenligne sine resultater med snittet for hele kullet. Vi inkluderte også karakterfordelingen for hele klassen slik som vist i Fig. 1.

Tabell 1. Tabellens venstre marg representerer poengintervallet det er mulig å oppnå for hver oppgave, med maksimalt 10 poeng. I tabellen fremkommer antall besvarelser fordelt på hvilke poeng de har fått gitt hver deloppgave.

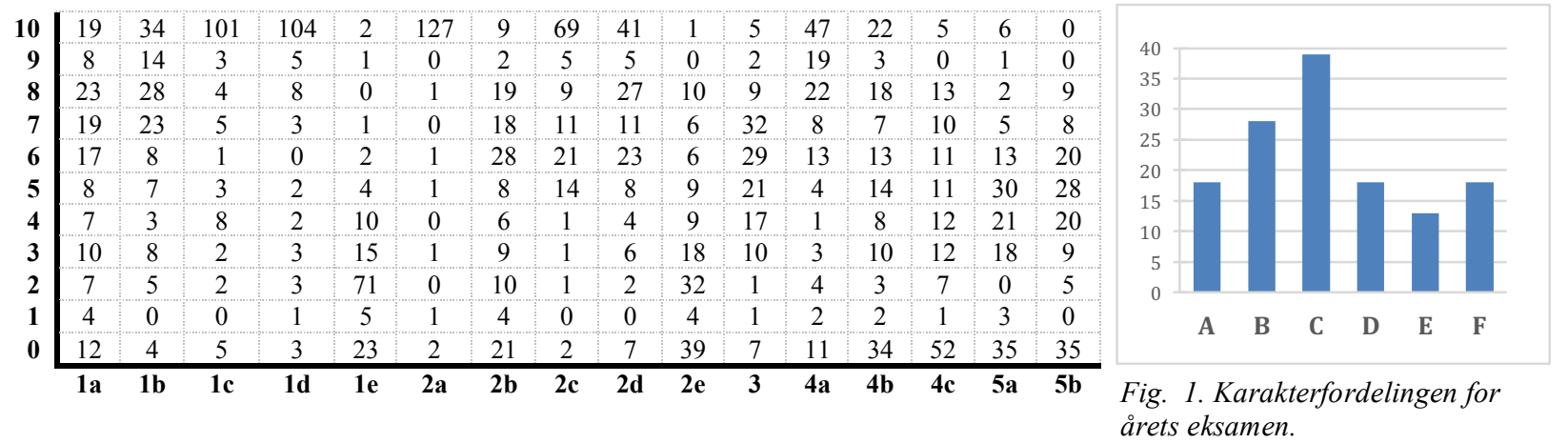

Tabell 2. Snittpoeng for hver deloppgave for hele året kull.

\begin{tabular}{c|c|c|c|c|c|c|c|c|c|c|c|c|c|c|c|}
$\mathbf{1 a}$ & $\mathbf{1 b}$ & $\mathbf{1 c}$ & $\mathbf{1 d}$ & $\mathbf{1 e}$ & $\mathbf{2 a}$ & $\mathbf{2 b}$ & $\mathbf{2 c}$ & $\mathbf{2 d}$ & $\mathbf{2 e}$ & $\mathbf{3}$ & $\mathbf{4 a}$ & $\mathbf{4 b}$ & $\mathbf{4 c}$ & $\mathbf{5 a}$ & $\mathbf{5 b}$ \\
\hline 5,95 & 7,31 & 8,71 & 8,99 & 2,24 & 9,65 & 4,99 & 8,13 & 7,19 & 2,77 & 5,55 & 7,42 & 4,91 & 3,31 & 3,65 & 3,77
\end{tabular}

\section{METODE - «AUTOMAGISK» SYSTEM}

Vanlig sensureringsprosedyre er å sensurere «vertikalt», det vil si å rette samme deloppgave for alle studentene etter hverandre før man sensurerer neste deloppgave. «Horisontal sensurering» betyr å sensurere en hel besvarelse for en kandidat før man sensurerer neste kandidat. Det er både fordeler og ulemper med disse to måtene å sensurere på. For «vertikalt» argumenteres det at det gir en mer rettferdig vurdering, mens for «horisontalt» argumenteres det for et helhetlig inntrykk for den gitte kandidat som kan gi en mer presis vurdering. Forskjellene for dette skal ikke vi i denne artikkelen ta for oss, men vi belyser disse to metodene for sensurering og opphavet til systemet vi har utviklet tar for seg fordelene fra begge disse to metodene.

I begynnelsen sensurerte vi besvarelsene både «vertikalt» og «horisontalt». Formålet var å se hvordan hver kandidats besvarelse er i forhold til læringsutbyttet for emnet. Opphavet til systemet vi har utviklet kom først gjennom det å lese hele besvarelsen under ett, altså «horisontalt» og notere seg noen tanker og kommentarer for hva kandidaten viser. Til å begynne med gikk det med ca 50 minutter per besvarelse inkludert å skrive en individuell tilbakemelding for den konkrete besvarelsen. Et eksempel på tilbakemeldingsformen og innholdet er (varierte fra 10 setninger til over en side): 


\begin{abstract}
«Du viser jevnt over god forståelse for boolsk algebra. Enkelte feil gjør at du ender opp med stort avvik i forhold til riktige svar. Det å bruke litt mer tid til å skrive tydeligere vil gjøre det lettere å forstå dine svar. Det er enkelte steder som du kunne ha kontrollregnet slik at du var helt sikker på at løsningen du presenterer er korrekt.»
\end{abstract}

Etter en del (25 stk) besvarelser begynte vi å se en trend i våre tilbakemeldinger, det var mye av det samme som gikk igjen. Tiden for å gi tilbakemelding gikk også jevnt nedover og konvergerte mot 30 minutter per besvarelse. Etter en egenkritisk gjennomgang av disse tilbakemeldingene fant vi ut at det er en evaluering av kandidatens prestasjon, men i liten grad en faglig forståelse. Det er den faglige tilbakemeldingen som ivaretar det faglige aspektet. Dermed fokuserte vi mer på å gi tilbakemeldinger til kandidatene om deres evne til å formidle faget og kunnskapen de besitter, altså mer en funksjonell enn deklarativ forståelse. Videre ønsket vi å gi en mer integrert profesjonell kompetanse i tilbakemeldingen og forslag til hva studenten kan gjøre fremover, helt i tråd med feedforward prinsippet. Dermed valgte vi å endre fokuset fra å vurdere memoreringen av fakta og deres regneegenskaper til å utvikle studentenes evne til å produsere respons på oppgaver som er divergente (avvikende) og sammensatte, altså på et høyere nivå i Blooms taksonomi [11]. På denne måten kan studentene demonstrere høyere kognitive forståelse og høyere profesjonsekspertise, spesielt med hensyn på presentasjon. Disse fokusendringene gav opphav til å finne fellestrekkene ved tilbakemeldingene vi allerede hadde opparbeidet. Det utkrystalliserte seg enkelte kriterier, ikke nødvendigvis de eneste og beste, men personlige kriterier vi som faglærer i emnet mener studenten har nytte av å vite og som kommer godt med i en feedforward tilbakemelding. For hvert kriterium brukte vi skala med følgende tegn: ' $\div$ ', $0,{ }^{\prime}+$ '.

Forståelse $(\boldsymbol{F})$ - Det vanskeligste kriteriet å kunne gi en helhetlig vurdering på. I enkelte oppgaver vil kandidaten kunne vise god forståelse, mens i andre oppgaver er forståelsen fraværende. Allikevel sitter vi igjen med en viss oversikt over studentens samlede forståelse for faget og det er hovedsakelig det vi også evaluerer. For å få fram et mer nyansert bilde av forståelse vil det være underpunkter i $(G)$ som kan være bedre egnet til dette formålet.

Kritisk evne (K) - Det er enkelte oppgaver som utfordrer kandidaten til å være kritisk til sine svar om de avviker fra hverandre når de blir bedt om å løse en oppgave på ulike måter. Dette var spesielt aktuelt for oppgavene 1a, 1b, 1d, 1e, 2b, 2c, 2d, 4a, 4b, 4c, totalt 49\% av årets eksamen.

$\underline{\boldsymbol{R} y d d i g h e t}(\boldsymbol{R})$ - En evaluering av kandidatens struktur og ryddighet for hele besvarelsen.

Skrift og språk $(\boldsymbol{S})$ - Hovedsakelig tydeligheten i besvarelsen. Har kandidaten lagt til rette for at det skal være lett å lese og forstå det de formidler/beskriver. Formidler også kandidaten den faglige kompetansen sin gjennom å «snakke faglig», bruke et faglig språk og terminologi.

Blanke svar / ubesvarte oppgaver (O) - Totalt bestod eksamen av 16 ulike oppgaver med ulik vektfordeling. Her har vi notert oss hvor mange oppgaver som står ubesvart og hva det utgjør i prosent for hver eneste kandidat. Her har vi ikke brukt vurderingstegn, men heller gruppert direkte antall ubesvarte oppgaver i intervaller av (0), (1-3), (4-6), (7->).

Generelt $(\boldsymbol{G})$ - Det er en del nyanser og generelle punkter som ikke blir fanget opp av de ovennevnte kriteriene. Disse kan grupperes inn i:




Forklaring til tankene (FT) - enkelte steder gjør kandidaten antagelser eller feil som gjør det vanskelig å følge tanken. Derfor er en tilbakemelding å oppfordre kandidaten til å gi en forklaring til tanken som ligger bak løsningen.

Tid til viktige oppgaver (TVO) - enten så er en del av de viktigste oppgavene (les høyeste vektende) ikke besvart, eller at kandidaten har valgt å svare særdeles kort. Tydelig at kandidaten har godt av å være mer bevist på vekting av eksamensoppgaver.

Tid til teori (TT) - ettersom årets eksamen hadde to åpenbare teorispørsmål (10\% samlet), så var det også i 1c, 1d, 1e, 2e, 3, 4c spor av å vise til teori og begreper i faget, dermed blir samlet vekting for teori litt i overkant av 30\%. Denne tilbakemeldingen går mest ut på at man skal se på teorioppgavene som viktige med hensyn på å fremvise kunnskapen sin, ikke velge enkle svar uten å utdype fordeler/ulemper osv.

Tidsdisposisjon (TD) - eksamen har en tidsbegrensning på 4 timer. Enkelte kandidater disponerer tiden feil ved å bruke for lang tid på enkelte oppgaver og det er tydelig at utover i besvarelsen blir både språk, skrift og presentasjon meget kort og fremstår som hastearbeid. Et par kandidater har også skrevet at de har kommet til kort med hensyn på tid.

Eksamenstrening (E) - når kandidaten viser ustrukturert og uprioritert løsning på de vektede oppgavene, er det anbefalt å få mer eksamenstrening.

Tid til Kontroll (TK) - dette punktet gjelder hovedsakelig for regneoppgavene i eksamen. Mange kandidater regnet litt feil, mye på grunn av slurvefeil. Dette kan enkelt unngås ved å sette av tid til kontroll av utregningen, gjerne ved å finne alternative måter å løse samme oppgave på for så å se om svarene blir like.

Presentasjon (P) - siden kriteriet om skrift og språk ikke er omfattende nok til å ta inn formidling av faget er dette punktet inkludert i evalueringen. Dette går på hvordan kandidaten presenterer sin løsning og formidlingen av faget generelt.

Hver besvarelse fikk derfor en vekting for hvert kriterium som ble samlet $\mathrm{i}$ et dataprogram om automatisk genererte resultatet fordelt på kriteriene. For å kunne lage en automatisk generert tilbakemeldingstekst, ble det utarbeidet en matrise med tekstfraser for hva hvert enkelt kriterium med ulik vekting betyr. For eksempel ble det skrevet en tilbakemeldingstekst som faglærer/sensor mener en student burde få når han/hun f.eks. presterer til ' $\div$ ' på ryddighet. Alle frasene basert på verdien og vektingen av kriteriene blir dermed tilgjengelig for å hente ut og sette sammen i en sammenhengende tekst. Det er dette vi kaller for automagisk tilbakemelding. Det er en del automatikk, men «magien» er å utforme gode kriterier som har gode og konstruktive tilbakemeldingsfraser. Dette satt sammen gir en fin flyt i tilbakemeldingen til studentene for deres besvarelse. Det ble av estetiske årsaker laget en ferdig mal i et tekstprogram (f.eks. MS Word) som automatisk innhenter tilbakemeldingen og den faglige vurderingen og sender dette ut i e-post til studentene, se Fig. 2 for et eksempel av en reell tilbakemelding. Denne tilbakemeldingen som studentene får er individuell i den forstand at (a) mengden av tilbakemelding og (b) hva som er vektlagt og i teksten. Mengden av tilbakemelding er proporsjonalt med hvor mange ' $\div$ ' eller ' + ' studenten har fått for et gitt kriterium gjennom hele eksamensbesvarelsen. Det akkumulerte antallet gir en verdi eller vekt som er direkte sammenkoblet til en tekstfrase. For å nyansere de ulike vektingene brukes ordvalg som god, delvis, varierende, manglende, svak, fraværende med mer. Det som gjør systemet i stand til å produsere individuell tilbakemelding er på grunn av at hver besvarelse består av alle de 
ovennevnte kriteriene med en nivådeling/nyansering på tre eller flere, dermed får vi en stor flerdimensjonal matrise med tekstfraser som danner grunnlaget for tilbakemeldingen.

Fig. 2. Et eksempel for en tilbakemelding til en student.

Min vurdering av din besvarelse fordelt med poeng pr oppgave er:
\begin{tabular}{c|c|c|c|c|c|c|c|c|c|c|c|c|c|c|c|c|c|c|c|c|c|c|c|c|}
$\mathbf{1 a}$ & $\mathbf{1 b}$ & $\mathbf{1 c}$ & $\mathbf{1 d}$ & $\mathbf{1 e}$ & $\mathbf{2 a}$ & $\mathbf{2 b}$ & $\mathbf{2 c}$ & $\mathbf{2 d}$ & $\mathbf{2 e}$ & $\mathbf{3}$ & $\mathbf{4 a}$ & $\mathbf{4 b}$ & $\mathbf{4 c}$ & $\mathbf{5 a}$ & $\mathbf{5 b}$ \\
\hline 8 & 9 & 10 & 10 & 5 & 10 & 0 & 7 & 6 & 1 & 5 & 10 & 7 & 4 & 3 & 4
\end{tabular}

Strukturen i besvarelsen din er delvis ryddig og tydelig. Du har på dette området forbedringspotensial og jeg vil anbefale deg at du er litt mer bevisst på strukturering til neste eksamen og gjerne invester litt mer tid på det. Håndskriften din er til tider litt vanskelig å tyde. Hovedsakelig er den god, men tenk litt mer bevisst på dette ved neste skriftlige eksamen. Prøv å gi svar på alle oppgavene, selv om du ikke kan eller forstår oppgaven. Det gir deg mulighet for høyere samlet uttelling for besvarelsen din. Selv om en oppgave er feil eller mangelfull, vil du allikevel kunne vise til kunnskap som gjør at du får noe uttelling. Det gir et dårlig inntrykk å være selektiv. Du viser varierende forståelse på de ulike oppgavene i besvarelsen. Kollokviesamtaler og regneøvelser kan bidra positivt for en økt forståelse og formidling av faget. Enkelte av oppgavene $\mathrm{i}$ årets eksamen har vært utformet slik du må ta noen kritiske vurderinger av svarene dine. Det er lagt opp til at du på eget initiativ skal være kritisk og dele refleksjonen med sensor. På dette punktet har du delvis vist kritiske evner og her har du forbedringspotensial. Der du er usikker på løsningen av oppgaven og svaret ditt er det desto viktigere at du deler dine refleksjoner med sensor. Alle oppgavene på eksamen er oppgitt med en prosentmessig vekting. Disse prosentsatsene er ikke bare ment som veiledning for tidsbruk men også hvor viktige de er i forhold til vurderingen av din besvarelse av eksamen. Høyere prosentsats gir høyere uttelling og det er dermed viktigere å ha fullverdige svar på dem. Her har du en del å tjene på å gå nøye igjennom hva du har svart på de aller viktigste oppgavene. Jo mer tid og ressurs du setter av til de mest tellende oppgavene jo mer uttelling får du samlet sett på eksamen. Det å sette av litt tid til å kontrollere svarene etter endt eksamen er utrolig viktig og nyttig. Mange slurvefeil vil kunne unngås. Tenk på hvordan du vil disponere tiden slik at du rekker å gå igjennom eksamen litt mer kritisk etter å ha løst alle oppgavene. På den måten vil du også kunne jevne ut noe av forskjellene på oppgavebesvarelsene dine. Den eneste muligheten for å gi et godt inntrykk til sensor er gjennom måten du presenterer dine løsninger. Alt fra måten du skriver (språkbruken) til hvordan det estetisk ser ut. Bruk gjerne litt mer tid på å planlegge hvordan du vil presentere din løsning. Hvor på arket du skal skrive hva og ikke minst hva vil du fokusere på. Ha det mest mulig oversiktlig og ryddig, på den måten vil det være lettere for sensor å se hvor utfordringene eller manglene i oppgaven ligger.

\section{RESULTATER - STUDENTENES TILBAKEMELDING}

For å kunne samle inn tilbakemelding fra studentene for dette pilotprosjektet ble det lagd et nettskjema som alle ble oppfordret til å fylle ut. Det var 67 studenter som har fylt ut nettskjema og det kom en rekke nyttige tilbakemeldinger om dette pilotprosjektet. Nettskjemaet bestod av tre åpne spørsmål med fritekstblokker. Spørsmålene var (1) hva de synes om tilbakemeldingen, (2) hvordan de synes den samsvarte med sin egen oppfatning av eksamen, (3) om de vil anbefale en slik tilbakemelding for andre emneansvarlige og tilslutt en fritekst med mulighet for å dele tanker fritt. Nedenfor er det noen utvalgte kommentarer som vi mener representerer og oppsummerer tilbakemeldingene fra kandidatene.

\section{«Det er kanskje et ork, men fy fader hvor mye utbytte det gir til en student som faktisk vil forbedre seg!}

«Jeg synes det burde vare skriftlig tilbakemelding $i$ alle fag. For min egen del går jeg på universitetet for å lare, ikke for å samle på karakterer, og det er veldig nyttig å få tilbakemelding på hvorfor besvarelsen har blitt vurdert som den ble, uansett om man har fått en god eller dårlig karakter.»

«Jeg synes den traff veldig godt! Samtidig var det noen ting jeg var overrasket over - som jo er veldig bra. Om jeg hadde visst alt det rare jeg gjorde, ville jeg jo ikke ha gjort det. Det var lite «positivt» $i$ tilbakemeldingen, men jeg synes tonen du har brukt her er utelukkende respektfull og konstruktiv, så det er helt greit å ikke bli strøket med hårene på grunnskole-vis.»

«A få en slik tilbakemelding som student har utrolig stor nytteverdi med tanke på at man vanligvis får en minimalistisk 'feedback' som gir lite nytte til utvikling. Tilbakemeldingen gitt er overraskende konstruktivt og gir da et godt utgangspunkt for videre utvikling. Så hva synes jeg om tilbakemeldingen? Det var utrolig bra og dette er noe som burde bli gjort oftere!» 
Nordic Journal of STEM Education, Vol. 1, No. 1 (2017), pp 287-293.

«Det gir god forståelse og ro i sjela å få tilbakemelding. Trist å sitte i mørket og ikke få vite hvor du har gjort feil/hvordan sensor har tenkt. Tipper det hadde kuttet antall klager også.»

\section{DISKUSJON}

Vi har i denne artikkelen vist en ny og forbedret individuell tilbakemelding på skriftlig eksamen i forhold til tradisjonell måte å gi studentene tilbakemelding på. I hovedsak er tilbakemeldingen to-delt, hvor den ene delen tar for seg en utvidelse av den faglige tilbakemeldingen ved å gi studentene mer enn bare karakter. Vi gir studentene muligheten til å se hvordan de har besvart hver deloppgave og hvordan det er blitt sensurert i sammenheng med resten av årets kull. Vi mener det gir studentene bedre innsikt $i$ hvor de har manglende faglig kunnskap og hva de trenger å jobbe mer med. Den andre delen er en innovativ metode for faglærer og sensor å gi studentene tilbakemelding på evne til å formidle faget og kunnskap. Det nye systemet innebærer at faglærer må definere skriftlig (frase) hva en gitt verdi av et kriterium betyr. Det å ha flere kriterier og flere verdier gjør at man opparbeider en matrise av mulige tilbakemeldinger. De ulike tilbakemeldingene vil gjøre det lettere å kalibrere sensorene på tvers av faget. På den måten vil en sensor ha flere nivåer av forståelse for hva som kreves av studentene for de ulike deloppgavene. Spesielt er det viktig med reliabilitet i vurdering, slik som studier viser at sensorer vurderer eksamensbesvarelser svært ulikt [14]. Raaheim peker i denne sammenheng på at mangelen på kriterier og sensorveiledning er sentrale for å forklare mangelen på reliabilitet. Dette dataprogrammet er bygd på en videreutviklet sensorveiledning implementert $i$ et regneark med kriterier i en enkel database. Nå som flere og flere utdanningsinstitusjoner går over til digitale læring- og vuderingsmiljøer vil dette programmet lett la seg inkludere i en digital eksamensomgivelse.

Det å gi studenter et godt fundament og en tydelig forventningsavklarering så tidlig som mulig i studiet er veldig avgjørende for transisjonen fra elev-til-student [6]. Basert på tilbakemeldingen fra studentene om vårt arbeid ser vi at det er utrolig viktig å tilrettelegge for muligheten til at studentene kan forbedre seg og finne større motivasjon i studiet. Det er viktig å gi tilbakemelding til studentene, spesielt førsteåret da det er deres første eksamener og det er viktig at de lærer mest mulig. Vi mener programmet kombinerer transisjonen elev-til-student med å gi tilbakemeldinger med feedforward, spesielt rettet mot studentenes profesjonelle kompetanse [4], og dermed oppnår studentene bedre læring. Vurdering og tilbakemelding på kursaktiviteter og prestasjoner har stor innvirkning på studentenes læring [12-13]. Videre bidrar det kanskje også til at studentene gjør det bedre på studiet og får et bedre studieliv. I beste fall hever vi kollektivt nivået på studentene våre og oppnår høyere gjennomstrømning og studiepoeng produksjon. Særlig førsteårsstudenter kan tjene på å trene på vurdering og tilbakemelding. Det hjelper dem å forstå hva som kreves av dem i en hittil ukjent akademisk setting, og bidrar til å skape transparens og et ikke-truende læringsmiljø [15].

Siden dette nå i første omgang har vært et eget initiert pilotprosjekt, uten støtte fra instituttet, har det medgått mye tid i utviklingsfasen. Det har vært en del litteratursøk og mange ideer er tatt med og utprøvd. Etter en slik grundig førstepilot har vi gjort oss noen tanker om hvordan dette kan generaliseres og tilrettelegges for andre emner. Enkelte elementer i dette systemet er spesifikt for hvert eneste emne og vil innebære justeringer for hvert semester. Et forsøk på å estimere hva et slikt tilbakemeldingsoppsett vil representere i tidsforbruk for et emne viser at det går tid til å sette opp kriteriene med tilhørende fraser, utforme en mal for tilbakemelding, utprøve kriteriene i et utvalg av besvarelser og tilslutt koordinering mellom sensorene. Til dette regner vi med at det går med 18 timer som faglærer bruker. For selve evalueringen av hver besvarelse har vi gjennom empirisk talldata kommet frem til en økning på ca 5 minutter per besvarelse for 150 besvarelser. Det vil ta mindre tid ved å gjenbruke dette systemet med tiden og spesielt hvis vi kan få dette inn i digital eksamensform. Det er overveiende sannsynlig at disse tilbakemeldingene vil føre til høyere gjennomstrømning av studenter og økt studiepoeng produksjon som igjen vil berike instituttet. Videre kan dette også spare administrasjonen tid for å behandle begrunnelser for vesentlige ressurser og ikke minst $\mathrm{i}$ 
antall klagesaker. Basert på nyere undersøkelser har vi sett at noen færre studentene klager, men at de i hovedsak klager på en annerledes måte. Klagene er mer begrunnet og konkrete, spesielt rettet mot enkelt elementer som studentene mener de har fått for lite uttelling for. Slik vi opplever det vil det da være en enklere klageprosess fordi man kan isolere klagen til de elementene studentene har klaget på og se om det gir utslag for endelig karakter.

Helt avslutningsvis ønsker vi å trekke frem noen av våre egne personlige erfaringer med dette systemet. Det å lage eksamen i en tidlig fase av emnet har vært utrolig nyttig for oss som faglærere, selv om vi har undervist dette emnet i flere år og føler at vi er rimelig gode på å lage eksamensoppgaver. Siden vi hadde god tid til å justere oppgavene fikk vi også muligheten til å grave litt mer i hvordan man kan måle forståelsen for enkelte temaer, gjennom dialog med studentene på forelesninger. Med dette systemet for sensurering og etter så nøye gjennomgang av besvarelsene har vi som faglærere fătt en ny innsikt i hva majoriteten av studentene forstår og hva de ikke forstår. Vi får informasjon om hvilke temaer vi bør fokusere mer på og hva er de vanligste misoppfatningene blant kandidatene. Dette har ført til at vi kommer til å endre noe på det faglige innholdet og rekkefølgen på teorien i emnet. Ikke minst kan vi bruke dette grunnlaget til å fortelle til de nye studentene hva som er de vanligste misoppfatningene på de mer komplekse problemstillingene. Dette prosjektet har virkelig bidratt til positiv vekst for oss som faglærere, undervisere og ikke minst som personer.

\section{REFERANSER}

[1] Higgins, R., Hartley, P., Skelton, A. (2001), Getting the Message Across: The problem of communicating assessment feedback, Teaching in Higher Education, Vol. 6, No. 2, pp. $269-274$.

[2] Conaghan, P. and Lockey, A., (2009). Feedback to feedforward, Notfall+ Rettungsmedizin, Vol. 12, No. 2, pp.4548.

[3] Sadler, D.R. (2010), Beyond feedback: developing student capability in complex appraisal, Assessment \& Evaluation in Higher Education, Vol. 35, No. 5, pp 535-550.

[4] Baker, D.J., Zuvela, D. (2013), Feedforward strategies in the first-year experience of online and distributed learning environments, Assessment \& Evaluation in Higher Education, Vol. 38, No. 6, pp 687-697.

[5] Moesby, E. (2002), From Pupil to Student - a Challenge for Universities: an Example of a PBL Study Programme, Global Journal of Engineering Education, Vol. 6, No. 2, pp. 145-152.

[6] Roderick, M., Holsapple, M., Kelley-Kemple, T., Johnson, D.W. (2014), From High School to the Future: Getting to College Readiness and College Graduation, Society for Research on Educational Effectiveness.

[7] Malmi, L., Korhonen, A. (2004), Automatic Feedback and Resubmissions as Learning Aid, IEEE International Conference on Advanced Learning Technologies, pp. 186-190.

[8] Jiménez-González, D., Álvarez, C., López, D., Parcerisa, J.M., Alonso, J., Pérez, C., Tous, R., Barlet, P., Fernández, M., Tubella, T. (2008), Work in Progress-Improving Feedback Using an Automatic Assessment Tool, IEEE Frontiers in Education Conference, Session S3B.

[9] Hunter-Barnett, S., Murrin-Bailey, S., Should Audio Feedback Be Used Because It Is Easily Available or For Reasons of Pedagogy? In Proceedings of the 2nd International Conference on Computer Supported Education, pp 60-64.

[10] Siddiqi, R., Harrison, C.J., Siddiqi, R., Improving Teaching and Learning through Automated Short-Answer Marking, IEEE Transactions on Learning Technologies, Vol. 3, No. 3, pp $237-249$.

[11] Bloom, B.S. (Ed.). Engelhart, M.D., Furst, E.J., Hill, W.H., Krathwohl, D.R. (1956). Taxonomy of Educational Objectives, Handbook I: The Cognitive Domain. New York: David McKay Co Inc.

[12] van der Kleij, F. M., Eggen, T. J. H. M., Timmers, C. F., \& Veldkamp, B. P. (2012). Effects of feedback in a computer-based assessment for learning. Computers \& Education, 58(1), 263-272. doi:10.1016/j.compedu.2011.07.020

[13] van der Kleij, F. M., Feskens, R. C. W., \& Eggen, T. J. H. M. (2015). Effects of Feedback in a Computer-Based Learning Environment on Students' Learning Outcomes: A Meta-Analysis. Review of Educational Research. doi: $10.3102 / 0034654314564881$

[14] Raaheim, Arild (2000). En studie av inter-bedømmer reliabilitet ved eksamen på psykologi grunnfag. Tidskrift for norsk psykologiforening

[15] Rust, C. (2002). The impact of assessment on student learning, how can the research literature practically help to inform the development of departmental assessment strategies and learnercentred sssessment practices? Active Learning in Higher Education, 3(2), 145-158 